\title{
Aplikasi object-based image analysis untuk identifikasi awal permukiman kumuh menggunakan Citra satelit worldview-2
}

\author{
Prima Widayani \\ Departemen Sains Informasi Geografi, Fakultas Geografi Universitas Gadjah Mada, Indonesia \\ Email Koresponden: prima.widayani@gmail.com
}

Diterima: Januari 2018/Refisi: Mei 2018 Disetujui: September 2018

๑) 2018 Fakultas Geografi UGM dan Ikatan Geograf Indonesia (IGI)

\begin{abstract}
Abstrak Permukiman kumuh adalah perumahan yang mengalami penurunan kualitas fungsi sebagai tempat hunian. Tidak layak huni karena ketidakteraturan bangunan, tingkat kepadatan bangunan yang tinggi, dan kualitas bangunan serta sarana dan prasarana yang tidak memenuhi syarat, (UU No.1 Tahun 2011). Permukiman kumuh banyak ditemukan di kotakota besar termasuk di sebagian Kota Yogyakarta, karena tidak layak dari sisi keaman, kesehatan dan tidak sesuai dengan tata ruang kota, maka perlu penanganan kawasan permukiman kumuh ini. Sebagai upaya penanganan kawasan kumuh, dibutuhkan pemantauan kawasan permukiman kumuh secara berkelanjutan, sehingga perlu suatu identifikasi cepat untuk membantu pemetaan kawasan kumuh. Penelitian ini bertujuan untuk identifikasi awal permukiman kumuh menggunakan pendekatan Object Base Image Analysis (OBIA) serta menguji kemampuan interpretasi OBIA dalam melakukan pengenalan permukiman kumuh berdasarkan ciri fisik permukiman. Data yang digunakan berupa Citra Satelit Worldview-2 tahun perekaman 2016, data kawasan kumuh Kota Yogyakarta dari program KOTAKU Yogyakarta, dan data survey lapangan. Alat yang digunakan berupa GPS, computer yang dilengkapi dengan software Ecognition, ENVI dan ArcGIS.10.2. Langkah pertama yang dilakukan sebelum menjalankan proses OBIA adalah mengenali karakteristik permukiman kumuh baik dari studi literatur, perundang-undangan maupun pengamatan lapangan. Berdasarkan studi sebelumnya dapat disusun aturan/ kunci interpretasi untuk mendeteksi permukiman kumuh. Hasil identifikasi awal permukiman kumuh menggunakan OBIA dapat dilakukan berdasarkan analisis pola permukiman, kondisi jalan, tekstur, vegetasi dan jarak dengan sungai. Identifikasi permukiman kumuh di wilayah pinggiran sungai berdasarkan kondisi fisik permukiman menggunakan citra Wordview-2 mengasilkan ketelitian sebesar $82,14 \%$. Ketelitian ini dapat dikatakan baik sehingga kedepannya diharapkan dapat membantu identifikasi awal dalam rangka pemetaan permukiman kumuh terutama di wilayah pinggiran sungai..
\end{abstract}

Kata kunci : permukiman kumuh, object-based image analysis, worldview-2

\begin{abstract}
Slum are housing that has decreased the quality of function as shelter. Unfit for habitation due to building irregularity, high density of buildings, and quality of buildings and facilities that do not meet the requirements, (UU. No.1, 2011). Slums are found in big cities, including parts of Yogyakarta City, because it is not feasible from the side of safety, health and not in accordance with the spatial city, it is necessary to handle this slum area. As an effort to handle slum areas, sustainable monitoring of slum areas is required and needs a quick identification to help mapping the slums.

This study aims to identify slum using Object Base Image Analysis (OBIA) and tested OBIA's interpretation capabilities for the identification of slum based on physical characteristics of settlements. Satellite Images Worldview-2 is used as the main data, map of slums of Yogyakarta City from Kotaku Yogyakarta program, dat from field survey. The tool used in this research is GPS, computer equipped with software Ecognition, ENVI and ArcGIS.10.2. The first step taken before running the OBIA process is recognizing the characteristics of slums both from literature studies, legislation and field observations.

The result of early identification of slum using OBIA can be done based on analysis of settlement pattern, road condition, texture, vegetation and distance with river. The identification of slum in riparian areas based on the physical condition of settlements using Wordview-2 image yielded a precision of $82.14 \%$. This accuracy is good enough so that the future is expected to assist early identification in the framework of mapping the slums.
\end{abstract}

Keywords: object base image analysis, slum, worldview-2

\section{PENDAHULUAN}

Kota Yogyakarta merupakan kota dengan jumlah penduduk sebesar 412.331 jiwa (Dinas Kependudukan dan Prasarana Wilayah Provinsi DIY, 2016), jumlah ini tergolong padat mengingat luas wilayah Kota Yogyakarta hanya seluas $32,50 \mathrm{Km}^{2}$. Penduduk membutuhkan lahan untuk tempat tinggal dan tidak semua penduduk mampu membeli lahan dan membangun tempat tinggal yang layak, oleh sebab itu munculah permukiman yang kurang layak huni atau sering disebut permukiman kumuh. Di Kota Yogyakarta, terdapat 45 kelurahan dengan luasan 2,64 $\mathrm{km}^{2}$ yang masuk ke kawasan kumuh.

Menurut Undang-Undang No. 1 pasal 1 ayat 13 tahun 2011 tentang perumahan dan kawasan permukiman, dijelaskan bahwa permukiman kumuh adalah permukiman yang tidak layak huni karena ketidakteraturan bangunan, tingkat kepadatan bangunan yang tinggi, dan kualitas bangunan serta sarana dan prasarana yang tidak memenuhi syarat. 
Permukiman kumuh adalah permukiman yang mengalami penurunan kualitas fungsi sebagai tempat hunian.

Pada umumnya kawasan kumuh di Kota Yogyakarta berada di bantaran sungai, seperti bantaran Sungai Code, Sungai Winongo dan Sungai Gajah Wong. Ketiga bantaran sungai tersebut menjadi kawasan permukiman kumuh yang berkembang di Kota Yogyakarta. Menurut Dinas Permukiman dan Prasarana Wilayah Provinsi DIY terdapat beberapa 10 lokasi permukiman kumuh yang diprioritaskan penanganannya yang terletak di Kelurahan Bumijo, Kricak, Tegalrejo, Prawirodirjan, Ngupasan, Sorosutan, Purbayan, Brontokusuman, Baciro dan Klitren. Dari 10 lokasi tersebut kawasan yang akan ditangani terutama kawasan permukiman kumuh di bantaran sungai. Sebagai upaya menurunkan kawasan permukiman kumuh dan penataan kawasan, pemerintah telah mencanangkan program Kota Tanpa Kumuh (KOTAKU) dengan target pengurangan kawasan kumuh di Kota Yogyakarta hingga 80 hektar per tahun. Sebagai bentuk upaya mendukung program pemerintah, disiplin ilmu penginderaan jauh dan SIG dapat membantu memetakan kawasan kumuh dengan memanfaatkan data citra pengginderaan jauh resolusi tinggi menggunakan metode Object-Based Image Analysis (OBIA).

Deteksi permukiman kumuh menggunakan data penginderaan jauh dengan metode Object-Based Image Analysis pernah dilakukan oleh beberapa peneliti, antara lain: Kohli (2016) melakukan penelitian untuk mendeteksi keberadaan permukiman kumuh di Kota Pune dari citra satelit menggunakan metode Object Oriented Analysis. Hasil penelitian menunjukkan bahwa ciri tekstur yang berasal dari kontras level keabuan menjadi kunci utama identifikasi objek. Metrik spasial seperti ukuran segmen dan proporsi vegetasi dan builtup area juga digunakan untuk deteksi kumuh.

Aminipouri (2012) melakukan penelitian di Tanzania untuk mengestimasi jumlah penduduk di wilayah permukiman kumuh dengan menggunakan Orthopotho dengan resolusi 0,6 m. Metode yang digunakan adalah pendekatan Object Oriented Analysis. Hasil yang diperoleh akurasi klasifikasi permukiman sebesar 93\% dengan nilai kappa 0,82. Berdasarkan analisis nilai kappa, metode OAA baik digunakan untuk klasifikasi permukiman. Hasil prediksi jumlah penduduk diperoleh akurasi sebesar 91,7\%, nilai ini mengindikasikan bahwa estimasi jumlah penduduk yang dilakukan pada penelitian ini mendekati jumlah penduduk kenyataan.

Penelitian Shekhar (2012) mengenai pemetaan permukiman kumuh didasari oleh program deteksi kawasan kumuh dan upaya perbaikan kawasan kumuh. Data citra yang digunakan dalam penelitian ini adalah data Quickbird dengan metode interpretasi berorientasi objek menggunakan software eCognition.

Berdasarkan kajian penelitian dapat diketahui bahwa selain teknik interpretasi visual dan interpretasi berbasis piksel (spektral), terdapat pendekatan lain yang dapat digunakan untuk mengidentifikasi awal permukiman kumuh yaitu dengan metode Object Based Image Analysis. Interpretasi visual yang lebih banyak membutuhkan local knowledge dengan wilayah sempit. Interpretasi data penginderaan jauh untuk identifikasi permukiman kumuh menggunakan metode pixel based terkendala pada heterogenitas dan kompleksitas penggunaan lahan di wilayah perkotaan. Kondisi ini dapat menurunkan akurasi hasil interpretasi, oleh karena itu pada penelitian ini dicoba menggunakan metode OBIA yang diharapkan dapat mengatasi kompleksitas penggunaan lahan dan relative cepat digunakan untuk identifikasi awal permukiman kumuh pada daerah yang luas. Tujuan dari penelitian ini adalah :

1. Melakukan identifikasi awal permukiman kumuh menggunakan pendekatan Object Base Image Analysis (OBIA).

2. Menguji kemampuan interpretasi $O B I A$ dalam melakukan pengenalan permukiman kumuh berdasarkan ciri fisik permukiman.

Satelit optis Worldview-2 diluncurkan pada 8 Oktober 2009 dari pangkalan angkatan udara Vandenberg, California, USA. Cara kerja satelit Worldview-2 dapat diibaratkan sebagai sebuah kuas, menyapu bolak-balik untuk mengambil area yang luas dengan sekali sapuan citra multispektral. Worldview-2 juga menyediakan detil citra dengan resolusi spasial 0,5 m untuk pankromatik dan 2,4 m untuk multispectral. Gambar 1 merupakan gambar Satelit Worldview-2 dan contoh citra hasil perekamannya.


Gambar 1. Citra Satelit Worldview-2

OBIA merupakan pendekatan klasifikasi citra yang tidak hanya mempertimbangkan aspek spektral namun aspek spasial objek. OBIA merupakan teknik klasifikasi yang memperhatikan kesatuan objek berdasarkan rona dan tektur piksel. Proses awal OBIA adalah dengan melakukan segmentasi citra dengan memperhatikan kenampakan tekstural atau pola spasial (Xiaoxia et al,. 2004).

Segmentasi data penginderaan jauh dapat dilakukan dengan algoritma region growing / merging, deteksi batas, atau dengan kombinasi keduanya, misalnya algoritma ECHO (Extraction and Classification of Homogeneous) dan MORM (Mutually Optimum Region). Deteksi batas menggunakan asumsi bahwa 
dua piksel yang berdekatan dengan perbedaan nilai yang besar mewakili dua segmen yang berbeda. Ada tiga faktor yang mempengaruhi kondisi dan syarat pada segmentasi, yaitu skala/scale, shape, dan compectness.

Secara umum, daerah kumuh (slum area) diartikan sebagai suatu kawasan pemukiman atau- pun bukan kawasan pemukiman yang dijadikan sebagai tempat tinggal yang bangunan-bangunannya berkondisi substandar atau tidak layak yang dihuni oleh penduduk miskin yang padat. Ciri umum permukiman kumuh jumlah penduduk padat, kepadatan rumah tinggi, jalan sempit, fasilitas sanitasi tidak memadai, pada umumnya penduduk memiliki tingkat pendapatan rendah, rumah dibangun dari bahan bangunan yang tidak standar.

Penentuan kriteria kawasan permukiman kumuh dilakukan dengan mempertimbangkan berbagai aspek atau dimensi seperti kesesuaian peruntukan lokasi dengan rencana tata ruang, status (kepemilikan) tanah, letak/kedudukan lokasi, tingkat kepadatan penduduk, tingkat kepadatan bangunan, kondisi fisik, sosial, ekonomi dan budaya masyarakat lokal. Selain itu digunakan kriteria sebagai kawasan penyangga kota metropolitan seperti kawasan permukiman kumuh teridentifikasi yang berdekatan atau berbatasan langsung dengan kawasan yang menjadi bagian dari kota metropolitan.

\section{METODE PENELITIAN}

Secara garis besar penelitian ini terdiri dari 3 tahap yaitu tahap pertama adalah persiapan meliputi studi literatur dan pengumpulan data, tahap kedua adalah proses pengolahan data meliputi koreksi citra, pembuatan segmentasi, klasifikasi dan kerja lapangan. Tahap Akhir meliputi analisis hasil pengolahan data dan uji ketelitian. Penelitian ini mengambil lokasi di sebagian Kota Yogyakarta, khususnya di sebagian wilayah pinggiran Sungai Code.

Bahan yang digunakan dalam penelitian ini meliputi Citra Satelit Worldview-2 Kota Yogyakarta Tahun 2016, Peta Administrasi Kota Yogyakarta dari Bappeda Kota Yogyakarta, Peta lokasi permukiman kumuh Kota Yogyakarta Tahun 2016 dari program KOTAKU. Alat yang digunakan berupa seperangkat komputer yang dilengkap dengan Software Arc GIS 10.2., eCognition, cek list untuk mencatat hasil kerja lapangan dan GPS.
Data primer yang berupa Citra Satelit World View-2 dilakukan koreksi geometri dan radiometri. Selanjutnya dilakukan proses klasifikasi berorientasi objek diawali dengan tahapan segemetasi citra, software eCognition ini memiliki beberapa tipe algoritma segmentasi yaitu Chessboard Segmentation, QuadtreeBased Segmentation, Multiresolution Segmentation, Contrast Split Segmentation, Spectral Difference Segmentation dan Multi-Theshold Segmentation. Tipe algoritma segmentasi yang digunakan dalam penelitian ini adalah menggunakan algoritma Multiresolution Segmentation. . Segmentasi membuat sejumlah objek baru yang belum terdefinisi. Mungkin pada awalnya objek yang dihasilkan terlihat kasar namun dapat diperhalus kemudian dengan menggunakan berbagai macam rule set tambahan. Semakin sedikit jumlah objek baru yang terbentuk semakin mudah dalam pengerjaannya. Berikut ini rumus yang digunakan dalam Multiresolution Segmentation.

$$
\mathrm{Sf}=\mathrm{W}_{\text {colour }} \times \mathrm{H}_{\text {colour }}+\left(1-\mathrm{Wc}_{\text {olour }}\right) \times \mathrm{h}_{\text {shape }}
$$

\section{Dimana :}

$\begin{array}{ll}\mathrm{Sf} & \text { :fungsi segmentasi } \\ \mathrm{W}_{\text {colour }} & \text { : bobot parameter warna } \\ \mathrm{H}_{\text {colour }} & \text { : parameter warna } \\ \mathrm{Wc}_{\text {olour }} & \text { : bobot parameter bentuk } \\ \mathrm{h}_{\text {shape }} & \text { : parameter bentuk }\end{array}$

Citra hasil segmentasi ini berfungsi sebagai salah satu unit klasifikasi yang berdasarkan nilai statistik segmen dan bukan berdasarkan pada nilai piksel per piksel dan pembentukan segmen ini dapat dikatakan merepresentasikan satu kesatuan objek (Wibowo,2010). Citra yang telah tersegmentasi selanjutnya diklasifikasikan dengan menggunakan metode Rulesetbased classification

Penyusunan ruleset berdasarkan studi literatur, pengamatan di lapangan dan panduan identifikasi permukiman kumuh yang dikeluarkan oleh Kementrian PUPR. Hasil dari klasifikasi OBIA tersebut kemudian diuji akurasi dengan mengambil beberapa sampel dan diujikan dengan Peta Kawasan Kumuh dari Program KOTAKU. Gambaran umum dari penelitian ini disajikan dalam Gambar 2.

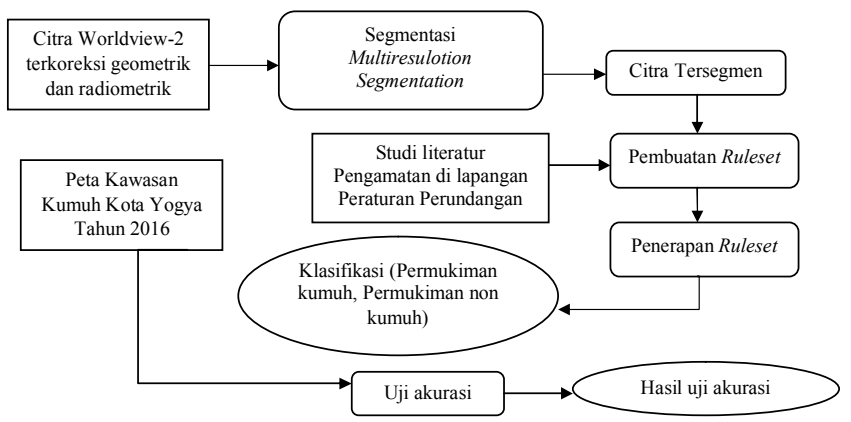

Gambar 2. Diagram alir 


\section{HASIL DAN PEMBAHASAN}

\section{Segmentasi citra}

Proses awal dari klasifikasi citra berbasis objek adalah segmentasi citra. Algoritma yang digunakan untuk melakukan segmentasi adalah Multiresolution Segmentation. Multiresolution Segmentation (MRS) yang dikembangkan oleh Baatz dan Schaepe (2000) merupakan algoritma segmentasi yang paling banyak digunakan. Proses segmentasi berbasis region growing ini dijalankan berdasarkan lima parameter yaitu skala (scale), warna (colour), bentuk (shape), kehalusan (smoothness) dan kekompakan (compactness). Parameter - parameter tersebut dapat dikombinasikan untuk mendapatkan hasil objek yang bervariasi, sehingga bisa disesuaikan dengan keinginan operator terkait pembuatan objek yang homogen pada resolusi yang diinginkan.

Pada penelitian ini scale parameter yang digunakan adalah 100, shape 0.3 dan compactness 0.1 . Parameter skala merupakan nilai abstrak untuk menentukan besarnya heterogenitas objek yang diperbolehkan dalam satu objek. Pada nilai skala yang sama, kenampakan heterogen akan menghasilkan ukuran objek yang lebih kecil daripada kenampakan homogen. Dipilihnya scale parameter 100 karena yang akan dideteksi adalah kawasan permukiman bukan individu bangunan.

Nilai parameter shape/bentuk diberi nilai 0,3. Nilai shape yang tinggi akan menyebabkan segmentasi lebih ditekankan pada tekstur, sedangkan penekanan pada tekstur tidak selalu menghasilkan objek citra yang dikehendaki. Parameter kekompakan digunakan untuk memisahkan objek yang kompak dengan objek yang tidak kompak yang memiliki perbedaan nilai spektral yang relatif rendah. Semakin besar nilai parameter ini, maka objek yang dihasilkan akan memiliki bentuk yang lebih kompak. Nilai ini merupakan penyimpangan dari bentuk kompak ideal yang diberikan. Hasil segmentasi dapat dilihat pada gambar 3 .

\section{Pembuatan Ruleset}

Object Base Image Analysis secara umum dapat dibagi menjadi 2 proses yaitu proses segmentasi dan proses klasifikasi. Terdapat beberapa metode klasifikasi menggunakan OBIA yaitu Field-base Classification, Simple-Sample-based classification, Multistage, Samplebased classification, Rule-based classification. Pada penelitian ini digunakan metode klasifikasi Rule-base classification. Metode ini digunakan karena dalam penentuan kawasan kumuh memerlukan berbagai macam kriteria.

Salah satu kesulitan dalam melakukan klasifikasi berdasar aturan adalah pada proses pembuatan aturan itu sendiri. Klasifikasi berdasar aturan sebenarnya merupakan upaya untuk men-transfer logika-logika interpretasi citra dari otak/pikiran dan pengalaman manusia ke dalam operasi di komputer. Strategi klasifikasi ini akan sangat berhasil jika faktor-faktor ini dipenuhi:

1. operator/ analis memiliki pengetahuan dan pengalaman yang tinggi dalam hal interpretasi citra dan objek kajiannya

2. operator/analis memiliki kemampuan menuliskan aturan interpretasi dalam pikirannya ke dalam bahasa komputer

Klasifikasiberdasarkan aturan memilikikeunggulan antara lain adalah operator dapat menyesuaikan pemilihan feature space yang lebih spesifik pada setiap proses pemisahan kelas sehingga klasifikasi lebih efektif. Kelemahannya adalah dalam menyusun aturan membutuhkan waktu yang lebih lama, proses pembuatan aturan yang sangat rumit karena kenampakan penutup lahan sangat bervariasi. Aturan yang dibuat tidak dapat diterapkan pada area yang lebih luas, sehingga aturan yang dituliskan pada Tabel 1 lebih cocok digunakan untuk identifikasi kawasan kumuh di sepanjang sungai.

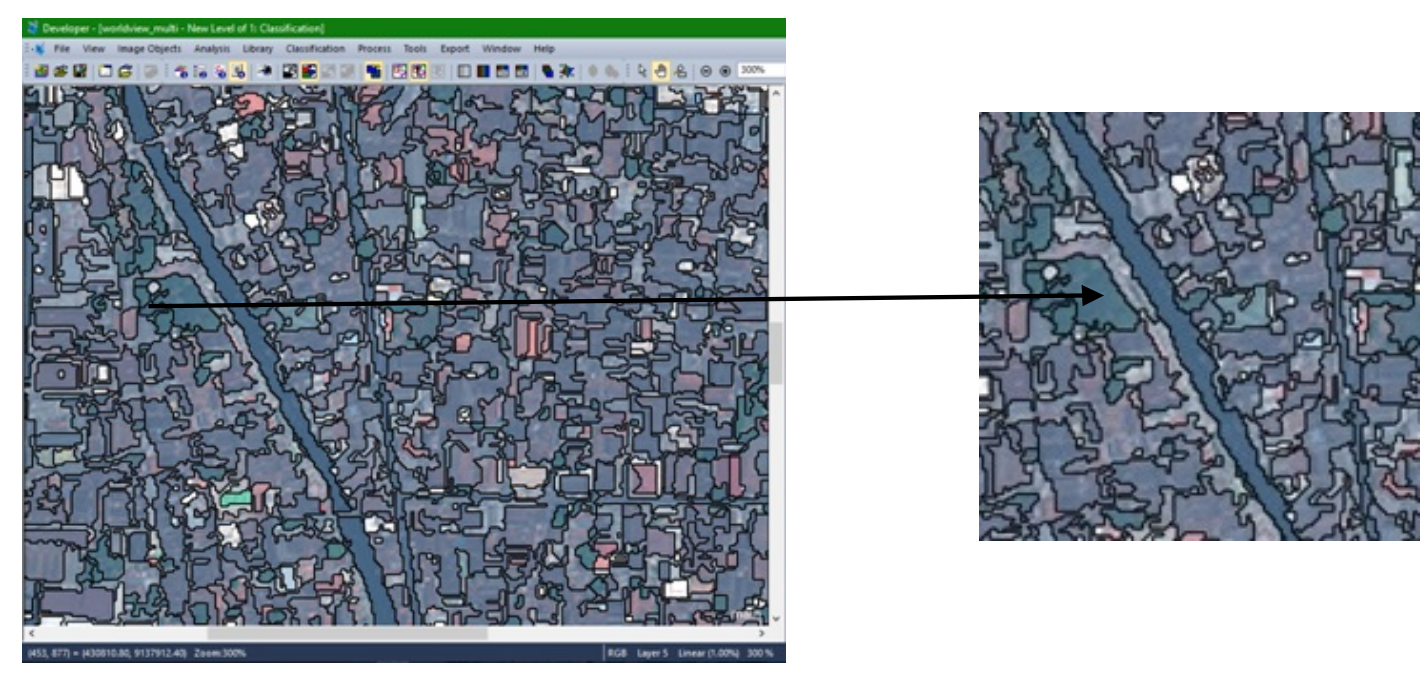

Gambar 3. Hasil Segmentasi (Sumber: Hasil Pengolahan data dengan ecognition, 2018) 
Tabel 1. Rule Klasifikasi OBIA untuk Identifikasi Awal Permukiman Kumuh

\begin{tabular}{lll}
\hline Seq No. & Classification Steps & Ruleset \\
\hline 1 & Classify Built-up & $0.5<$ NDVI $\geq 0.1 ; 1>V g N I R-B I>0 ;$ Rectangular Fit $>0.8$ \\
2 & Classify Not Built-up & $0.05 \geq N D V I \geq 0 ; 0 \geq V g N I R-B I \geq-1 ;$ Number of pixel $<140 p x$ \\
3 & Classify River & $2400 \geq$ Mean NIR-2 $>1200$ \\
4 & Classify Vegetation & NDVI $>0.3$ \\
5 & Classify Road & $0.51>$ MNDWI $>0.44$ \\
6 & Classify Slums & Shape Index $\geq 3.2 ;$ Compactness $>3$ \\
7 & Buffer along river & Within 50 pixel \\
\hline
\end{tabular}

Sumber : Hasil penelitian

\section{Permukiman Kumuh Hasil Klasifikasi OBIA}

Berdasarkan penerapan ruleset pada software eCognition dihasilkan klasifikasi permukiman kumuh dilihat dari segi kepadatan permukiman, kedekatan dengan sungai, kerapatan vegetasi, serta kondisi jalan. Dilihat dari Gambar 3, persebaran kawasan kumuh banyak terdapat di pinggiran sungai, walapun juga terdapat di wilayah yang bukan pinggiran sungai. Hal ini bisa terjadi disebabkan karena faktor kepadatan permukiman, mengingat wilayah penelitian berada di Kota Yogyakarta yang kondisi kepadatan rumahnya tinggi di hampir seluruh wilayah kota. Data hasil klasifikasi OBIA tentang identifikasi awal permukiman kumuh ini dapat membantu untuk meringankan kerja lapangan yang nantinya perlu dispesifikasikan lagi kawasan kumuhnya dengan menambahkan kriteria lain sesuai dengan panduan penetapan kawasan kumuh dari kementeria PUPR.



Gambar 3. Hasil klasifikasi OBIA kawasan kumuh 


\section{Uji Akurasi Identifikasi Awal Permukiman Kumuh Dengan $O B I A$}

Uji akurasi dilakukan guna mengetahui seberapa besar tingkat keberhasilan interpretasi. Sesuai dengan tujuan penelitian yang kedua bahwa metode interpretasi berbasis objek/OBIA yang digunakan untuk mengidentifikasi kawasan permukiman perlu dikaji efektifitas dan tingkat akurasinya. Uji akurasi hasil interpretasi dapat dilakukan dengan beberapa cara yaitu dengan membandingkan data hasil interpretasi dengan keadaan di lapangan atau membandingkan dengan data atau peta lain yang telah teruji kebenarannya dan dapat dijadikan referensi.

Pada penelitian ini hasil klasifikasi berbasis objek untuk identifikasi awal kawasan permukiman kumuh diuji akurasinya dengan Peta Kawasan Kumuh Kota Yogyakarta yang dibuat oleh program KOTAKU 2016. Program KOTAKU adalah program Kota Tanpa Kumuh yang dilaksanakan oleh pemerintah. Gambar 4 merupakan peta yang dijadikan referensi.

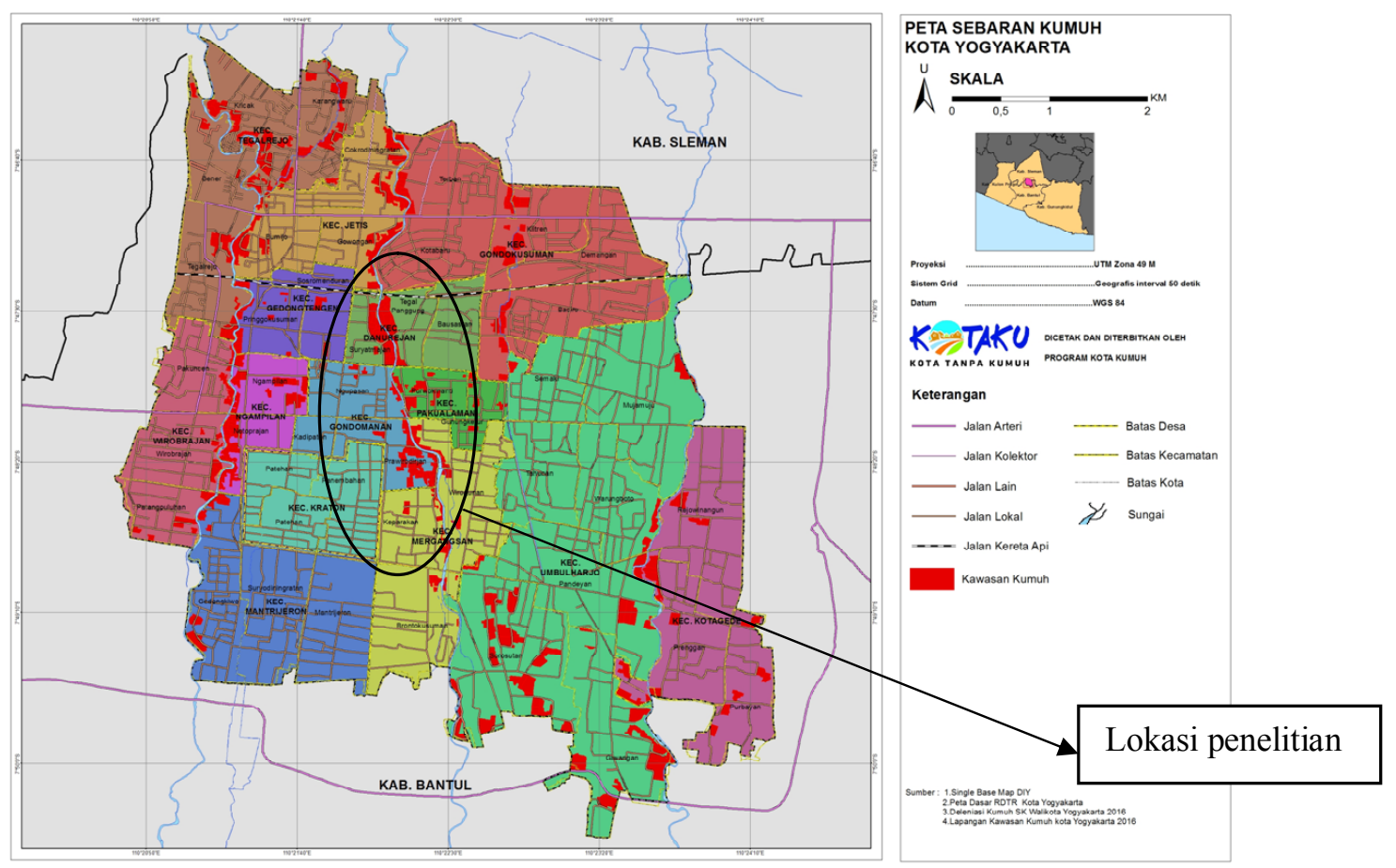

Gambar 4. Peta Kawasan Kumuh Kota Yogyakarta 2016 dari Program KOTAKU

Berdasarkan pengujian dengan menggunakan 28 titik sampel, diperoleh hasil uji akurasi klasifikasi OBIA untuk identifikasi kawasan kumuh sebesar 82,14\%. Hasil ini dapat dikatakan baik mengingat obyek yang diidentifikasi cukup spesifik dan membutuhkan kriteria-kriteria tertentu. Dengan hasil uji akurasi yang baik, diharapkan kedepannya metode OBIA dapat diterapkan untuk identifikasi awal kawasan kumuh terutama di wilayah pinggiran sungai. Untuk kawasan kumuh yang berada di tengah kota, perlu ditambahkan rule yang lain agar dapat dibedakan mana permukiman kumuh dan mana yang bukan. Tabel 2 dibawah ini merupakah perhitungan uji ketelitian interpretasi kawasan kumuh dengan metode OBIA.

Tabel 2. Perhitungan uji ketelitian

\begin{tabular}{lllll}
\hline & \multicolumn{2}{c}{ Ground Truth } & Total Baris & User Akurasi \\
\cline { 2 - 5 } & PL Lain & P.Kumuh & & \\
\hline PL lainnya & 12 & 1 & 13 & 75.00 \\
Citra P.Kumuh & 4 & 11 & 15 & 91.67 \\
Total Kolom & 16 & 12 & 28 & \\
Produser Akurasi & 92.31 & 73.33 & & 82.14 \\
\hline
\end{tabular}

Sumber : Hasil Perhitungan 
Secara visual juga dapat dilihat melalui gambar 5, adanya kesesuaian peta hasil OBIA dan Peta Kawasan kumuh Kota Yogyakarta dari program KOTAKU terutama kawasan kumuh yang terletak di pinggiran sungai. Kawasan kumuh yang teridentifikasi dan lokasinya bukan dipinggiran kota, masih dibutuhkan evaluasi lebih lanjut. Dengan demikian metode OBIA dapat digunakan untuk identifikasi awal kawasan kumuh, dikatakan sebagai identifikasi awal karena penentuan kawasan kumuh memerlukan banyak kriteria yang sudah ditetapkan oleh peraturan perundangan yang berlaku. Diharapkan dengan dilakukannya identifikasi awal kawasan kumuh dapat membantu proses pemetaan permukiman kumuh pada tahap selanjutnya.

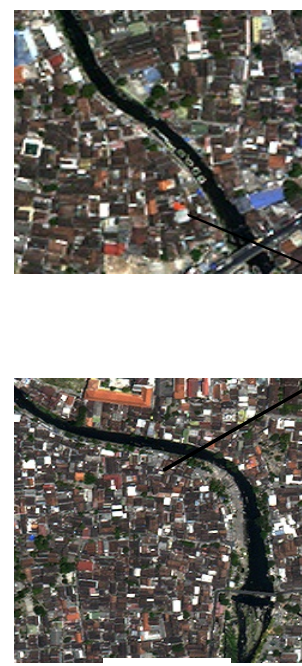

(a)

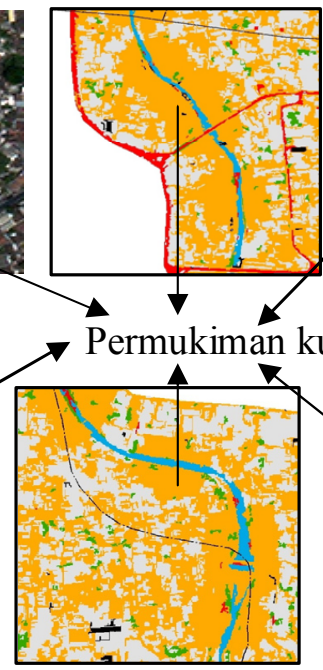

(b)

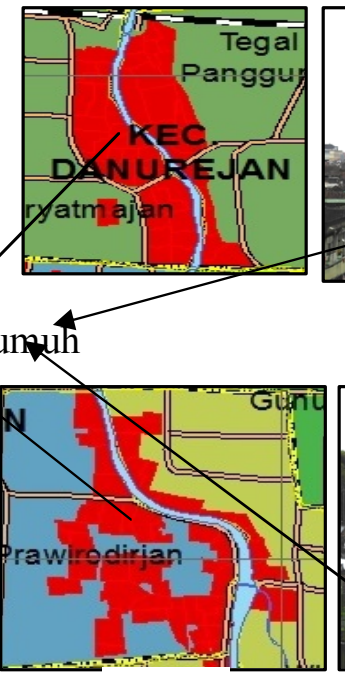

(c)
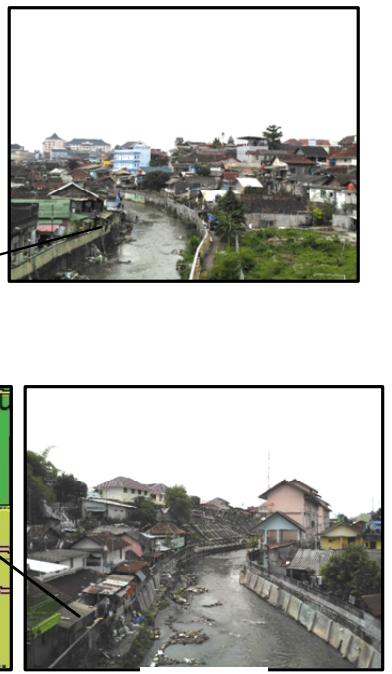

(d)

Gambar 5. (a) Potongan citra Worldview, (b) Hasil kasifikasi OBIA, (c) Peta Kawasan Kumuh, (d) Foto Lapangan

\section{KESIMPULAN}

Berdasarkan hasil penelitian ini dapat disimpulkan bahwa identifikasi awal permukiman kumuh menggunakan OBIA dapat dilakukan berdasarkan analisis pola permukiman, kondisi jalan, tekstur, vegetasi dan jarak dengan sungai. Identifikasi permukiman kumuh di wilayah pinggiran sungai berdasarkan kondisi fisik permukiman menggunakan citra Wordview-2 mengasilkan ketelitian sebesar $82,14 \%$. Ketelitian ini dapat dikatakan baik sehingga kedepannya diharapkan dapat membantu identifikasi awal dalam rangka pemetaan permukiman kumuh terutama di wilayah pinggiran sungai.

\section{UCAPAN TERIMAKASIH}

Peneliti mengucapkan terimakasih yang sebesarbesarnya kepada Bappeda Kota Yogyakarta yang telah memberikan ijin penelitian dan data Kawasan Kumuh Kota Yogyakarta melalui Program KOTAKU. Ucapan terimakasih juga peneliti sampaikan kepada Ketua Departemen Teknik Kebumian Sekolah Vokasi UGM. Tak lupa ucapan terimakasih untuk Aulia Yogi dan Risky Yanuar yang telah membantu dalam penelitian ini. Tak lupa ucapan terima kasih kepada Ibu Iswari Nurhidayati, S.Si, M.Sc, atas data citra satelitnya dan Aulia Yogi serta Risky Yanuar yang telah membantu dalam penelitian ini.

\section{DAFTAR PUSTAKA}

Anderson, J. H., E., Roach J.T., \& R.Wittmer,. (1976). A Land UseAnd Land Cover ClassificationSystem For Use With RemoteSensor Data.Geologica ISurvey Professional Paper 964.Washington : United States Government Printing Office.

Aminipouri, M., 2012. Object-Oriented Analysis of Very High Resolution Orthophotos For Estimasing The Population of slum Areas, Case of DarEs-Salaam, Tanzania. International Society of Photogrammetry and Remote Sensing (ISPRS). Proceedings/XXXVIII

Baatz, Schaepe .2000. Multiresolution Segmentation-an optimization approach for high quality multi scale image segmentation. Geographische Information Verarbeitung XII.Wichmann Karlsruhe.pp12-23.

Congalton, R.G. dan Green, Kaas,2008. Assessing The Accuracyof Remotely Sensed Data:Principles and Practices (2ndEdition), Boca Raton: CRCPress, Taylor and Francis Group.

Dinas Kependudukan dan Prasarana Wilayah. 2016. Permukiman Kumuh di Yogyakarta. http:// kependudukan.jogjaprov.go.id. Diakses pada 25 Februari 2017.

DigitalGlobe.2013. Worldview2Specification.http:// digitalglobe/satelit information. Tanggal akses: 20 Februari 2017. 
Kohli, D,. Sliuzas, Stein, A. 2016. Urban Slum Detection Using Texture And Spatial Metrics Derived From Satellite Imagery. Journal of Spatial Science. No.61, Vol.2, 405-426.

McCoy, Roger. (2005). FieldMethods in Remote Sensing. New York: The Gildford Press

Shekhar, S. 2012. Detecting Slums For Quickbird Data In Pune Using An Object Oriented Approach. International Archives of the Photogrammetry, Remote Sensing and Spatial Information Sciences, Volume XXXIX-B8.

Veljanovski, T., Kanjir,U., Pehani, P., 2012. ObjectBased Image Analysis of VHR Satellite Imagery for Population Estimation in Informal Settlement Kibera-Nairobi, Kenya. Remote SensingApplication.-Book Chapter. Published: June 13, 2012 under CC BY 3.0 license.

Undang-Undang No 1 Tahun 2011 tentang Perumahan dan Kawasan Permukiman . http://peraturan.go.id. Diakses pada Mei 2017

Wibowo, W.T., 2010. Studi Komparasi Klasifikasi Multispektral dengan Klasifikasi Berorientasi Objek untuk Ekstraksi Penutuplahan: Menggunakan Citra Alos Avnir-2 dan Citra Alos Pan-Sharpened. Skripsi. Universitas Gadjah Mada.Yogyakarta.

Xiaoxia, S., Jixian, Z., dan Zhengjun,L., 2004. A Comparison of Object-Oriented and PixelBased Classification Approachs Using Quickbird Imagery. Chinese Academy of Surveiing and Mapping, Beijing, China. 